\title{
Extensive skull base osteomyelitis found radiologically after resolution of otitis externa
}

\author{
Catriona Shenton 지 , Meera Beena, Amy Rhodes
}

Otorhinolaryngology, Blackpool Victoria Hospital, Blackpool, UK

\section{Correspondence to} Dr Catriona Shenton; trioshenton@gmail.com

Accepted 1 July 2020

\section{DESCRIPTION}

An 80-year-old diabetic man presented with a 6-week history of left otalgia, which had not improved with topical and oral antibiotics from the GP. He was treated with regular aural microsuction, antibiotic and steroid dressings. He had recurrent ear canal granulations removed in clinic. Over this 5-month period, he received courses of three different oral antibiotics. His otalgia and ear discharge resolved, with a normal ear canal on examination.

He was reviewed in clinic 8 days later, where he reported increasing neck pain, dysphagia, weight loss and lethargy. On examination, granulations were seen along the posterior wall of his left ear canal, palatal elevation was absent, with tongue deviation to the left. MRI (figure 1) showed an infective collection behind the left nasopharynx crossing the midline. The left carotid sheath was encased, with $\mathrm{C} 1$ osteomyelitis and bilateral mastoid effusions, worse on the left. A subsequent CT (figure 2) showed left skull base osteomyelitis including the occipital condyle, petrous part of the temporal bone, styloid process and anterior aspect of the clivus. Erosion of the carotid canal and foramen ovale were noted. A soft tissue lesion with multiple air foci in the preclival region extended across the midline up to the nasopharynx and contained fragments of destroyed bone.

Examination of the prevertebral lesion via endoscopic sinus surgery approach showed what appeared to be an abscess cavity to the left of the midline, but no pus; biopsy showed no malignancy.

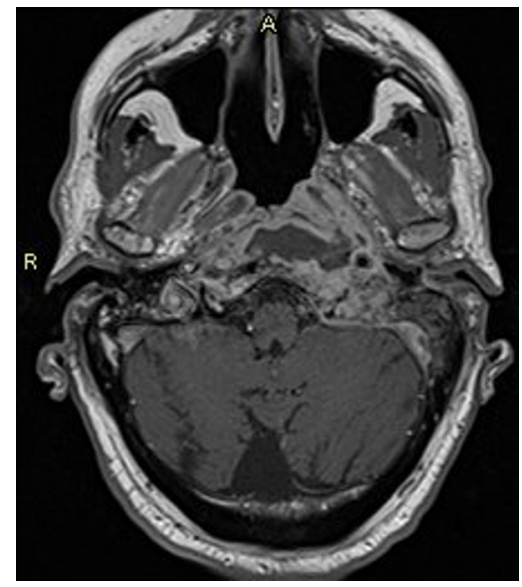

Figure 1 Axial T1 post-contrast MRI. Central and leftsided soft tissue thickening/inflammatory changes with enhancement and central necrosis/collection. Encasement of left internal carotid artery along with clivus erosion.

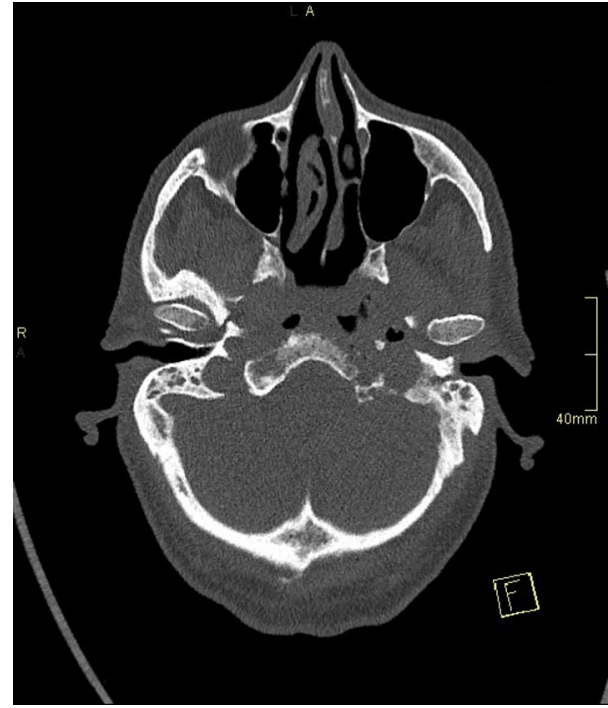

Figure 2 Axial non-contrast CT at skull base level. Erosive changes of the clivus anteriorly with overlying soft tissue thickening.

Despite 5 weeks of intravenous tazocin and metronidazole as per culture and sensitivities, he continued to deteriorate clinically. He developed stridor because of bilateral vocal cord palsy, which required surgical tracheostomy. His intravenous antibiotics were changed to meropenem, with improvement in his symptoms and general condition.

Skull base osteomyelitis remains $\operatorname{rare}^{12}$ and is a recognised life-threatening complication of malignant otitis externa. ${ }^{3}$ Other case reports describe central skull base osteomyelitis in the absence of otitis externa. ${ }^{4}$ This case shows extraordinary extension across to the contralateral skull base, diagnosed on imaging after clinical resolution of the patient's otitis externa.

There are three important clinical messages here. (1) Have a high index of suspicion for malignant otitis externa when treating chronic

\section{Learning points}

- Have a high index of suspicion for malignant otitis externa when treating chronic otitis externa, especially in immunocompromised patients.

- Continue 3 months of effective antibiotic treatment after diagnosing malignant otitis externa, even when clinical improvement is seen 
otitis externa, especially in immunocompromised patients. (2) Once the diagnosis of malignant otitis externa is made, 3 months of effective antibiotic treatment is required even when the ear canal heals and the patient appears well. (3) Have a low threshold to review antibiotic therapy despite culture and sensitivities if no clinical improvement is seen.

Contributors CS was the main author of the case report. MB and AR both contributed to the editing and review of the report.

Funding The authors have not declared a specific grant for this research from any funding agency in the public, commercial or not-for-profit sectors.

Competing interests None declared.

Patient consent for publication Obtained.

Provenance and peer review Not commissioned; externally peer reviewed.
ORCID iD

Catriona Shenton http://orcid.org/0000-0001-9894-6248

\section{REFERENCES}

1 Khan MA, Quadri SAQ, Kazmi AS, et al. A comprehensive review of skull base osteomyelitis: diagnostic and therapeutic challenges among various presentations. Asian J Neurosurg 2018;13:959.

2 Das S, Iyadurai R, Gunasekaran K, et al. Clinical characteristics and complications of skull base osteomyelitis: a 12-year study in a teaching hospital in South India. J Family Med Prim Care 2019;8:834

3 Bruschini L, Berrettini S, Christina C, et al. Extensive skull base osteomyelitis secondary to malignant otitis externa. J Int Adv Otol 2019;15:463-5.

4 Chang PC, Fischbein NJ, Holliday RA. Central skull base osteomyelitis in patients without otitis externa: imaging findings. AJNR Am J Neuroradiol 2003;24:1310-6.

5 Chawdhary G, Hussain S, Corbridge R. Delayed diagnosis of central skull-base osteomyelitis with abscess: case report and learning points. Ann R Coll Surg Engl 2017;99:e24-7.

Copyright 2020 BMJ Publishing Group. All rights reserved. For permission to reuse any of this content visit

https://www.bmj.com/company/products-services/rights-and-licensing/permissions/

BMJ Case Report Fellows may re-use this article for personal use and teaching without any further permission.

Become a Fellow of BMJ Case Reports today and you can:

- Submit as many cases as you like

- Enjoy fast sympathetic peer review and rapid publication of accepted articles

- Access all the published articles

Re-use any of the published material for personal use and teaching without further permission

Customer Service

If you have any further queries about your subscription, please contact our customer services team on +44 (0) 2071111105 or via email at support@bmj.com.

Visit casereports.bmi.com for more articles like this and to become a Fellow 